\title{
Anniversaries
}

\section{RUSSELL ARCHIVES: THE EARLY DAYS}

\author{
John G. SLater \\ Philosophy / U. of Toronto \\ Toronto, ON, Canada M5R 2M8 \\ JGSI930@GMAIL.COM
}

On the occasion of the 5oth anniversary of the founding of the Bertrand Russell Archives at McMaster University in Hamilton, Ontario, Canada, the author recalls his connection to that memorable event. The origin and development of the plan that led to the continuing publication of volumes in The Collected Papers of Bertrand Russell is sketched, and the author's role in giving Ronald W. Clark access to the Archives to write the first major biography of Russell is disclosed.

W henever I think of the Bertrand Russell Archives I immediately recall a day in August 1966 when I read a short piece in the day's New York Times announcing that his papers were on their way from his home in Wales to a literary agent's offices in London. That very day I went to see my boss, the chairman of Toronto's Philosophy Department, Thomas A. Goudge, who I knew was, like myself, an admirer of Russell's philosophical achievements. Together we decided to try to persuade our university to submit a bid. Goudge carried out our plan: he asked a Toronto professor on leave in England to visit the literary agent's offices and inspect the papers. His assessment being very positive, Goudge and higher officials prepared a submission to the Canada Council for funding. Shortly after its arrival in Ottawa we were asked to withdraw it, because McMaster too had an appeal for funding before the Council, prepared by its chief librarian, William Ready, who had persuaded both the Atkinson and the Laidlaw Foundations, to the Council's evident delight, to pay a large percentage of the expected cost. The reasonableness of the Council's request was unassailable, and Toronto withdrew and lent its support to McMaster's proposal.

I heard early in 1968 that McMaster had been successful in its bid and that, 
in addition to the papers, Ready had hired a young Canadian, Kenneth Blackwell, who had been sorting the papers in Russell's home, to come to McMaster and continue his work. Neither Ken nor I can remember how we met, but when we did I invited him to Toronto to determine whether there was anything I could do to promote the archives. On that first visit I heard how Ken, a student in British Columbia, had developed an intense interest in Lester Denonn's bibliography of Russell's writings and had discovered errors, but especially omissions, in it. He knew he could improve it. So he went to Wales and telephoned Russell's number and spoke to his live-in secretary. As fate would have it, Russell was in need of a helper just at that time to help get his papers ready for sale. So Ken was hired and worked until the books and papers were loaded for their trip to London. He went along and that is where he met Ready.

The deficiencies of the bibliography occupied much of our first meeting, but we also moved on to discussing what could be published from the archives. I knew Russell's books, indeed I had copies of most of them, and I was also acquainted with his philosophical articles. At the time I was only sketchily aware of his contributions to magazines, newspapers, and pamphlets of various kinds. This was the area in which Ken's bibliographical interest was very strong. He had already dreamed of collecting these ephemeral pieces and publishing them. This dream was later realized in The Collected Papers of Bertrand Russell. We began to discuss regularly how this might be done, and, after I July I969, when I assumed the chairmanship of the department and had a telephone on my desk for the first time we talked nearly every working day. We gradually honed his idea into a lengthy prospectus which was published in Russell: the fournal of the Bertrand Russell Archives, with an introduction by William Ready. A reading of the prospectus reveals a fairly clear summary of the nature of our discussions. Ken provided the detailed information and I acted as a sounding board and did some of the writing. It is probably safe to say that every sentence in it is a joint product. Meanwhile word was spreading of the possibility of a major editorial project being funded at McMaster, and, over time, commitments to join the editorial team were secured from Richard Rempel in the History Department, Andrew Brink in the English Department and an amateur Freudian, and Nicholas Griffin who had just joined the Philosophy Department and who has made major contributions to Russell scholarship.

With a prospective editorial team in place McMaster applied to the renamed Social Sciences and Humanities Research Council for funding. Our prospectus was central to the application because it showed that we had a full and well-considered plan for the project. What was proposed was an initial volume edited by all five editors, and then two streams, one philosophical and the other all the rest of his shorter works. The editorial work on these would 
be parceled out to individual editors or teams of editors. Funding for five years was requested, and to the astonishment of all of us we were awarded I. 6 million dollars in April I980. I think the fact that I was on the team may have helped, because the Council was charged with spreading its funds widely, and two universities trumps one. Whatever their reasoning I greatly benefited, because the Council awarded Toronto money to hire an assistant professor for five years to relieve me of half of my teaching duties. We hired James Robert Brown who went on to have a very distinguished career in our department.

I want now to return to the period right after the arrival of the archives in the spring of I968. In fairly short order I got to know William Ready who seemed to spend frequent weekends in Toronto, and on several occasions he invited me to join him for dinner. Our discussions were always about the ways in which the archives could be brought to the attention of scholars who might be able to exploit it and make it more widely known. Ready himself published a little book with that intention. One evening, shortly after Russell's death on 2 February 1970, he asked me if I would accompany Ken to London to join him in discussions with lawyers about outstanding matters and to meet Russell's publisher, Rayner Unwin. I agreed, but told him I had first to get a passport. With it in hand Ken and I spent several days in London meeting with at least two lawyers who were involved with various bits of unfinished business regarding the transfer of the papers to McMaster.

We went to Museum Street to see Rayner Unwin who had just assumed the chairmanship of Allen and Unwin in I968 on his father's death. The author of his obituary described the Unwin offices as Dickensian, and I can testify to the accuracy of that. There were dark corridors and shelves everywhere holding copies of the books the firm had published and many of them indeed looked their age. Ken pitched our proposal to Unwin and he was interested in publishing the books, but later when we got to the writing of a contract we found that he wanted the books in "camera-ready copy" which meant that the editors and McMaster did all the work except the printing and binding. I typed in every word in the five volumes I edited except the textual notes. Had computers not come along at this time I doubt we would have published very many volumes. Later when we were told the high price his firm was charging for the first volume, we objected and were told in no uncertain terms to keep our noses out of it. Pricing, Rayner wrote us, is done by the publisher and no one else.

Ken and I went back to London in August of 1970 for additional meetings with those managing Russell's estate, his former aides, and Rayner Unwin. On that trip we visited Russell's childhood home, Pembroke Lodge, near Richmond Park, and learned that on that site in 1754 was situated the cottage of a mole-killer whose job was to remove all the molehills which were interfering with the sport of deer hunting. It struck me as a fitting analogy of some 
of Russell's work in philosophy. We went to Hay-on-Wye in Wales to visit the bookstore Richard Booth was opening there with the promise, remarkably later carried out, of making this tiny town a centre for book selling. Richard himself entertained us. I recall our time with him in his very large house, unlike any other in Hay. I was especially amused to watch him pricing the books I had selected. He had only two prices: five shillings for thin volumes and ten for fat ones. The actual content or authors of the books did not seem to matter to him. Over the years I visited Hay every time I was in Britain and I bought hundreds of books there for my various collections.

On 24 August 1970 we took a delightful trip out of London to the quaint village of Lavenham in Suffolk to visit Colette O'Niel, whose real name was Lady Constance Malleson, famous as one of Russell's lovers. In her youth she had been an actress and in later years a novelist. Ken had written her arranging our visit and she had replied with detailed instructions for finding her cottage. We got there early and killed time by walking the street. At the appointed time we knocked on her door, and when she opened it she exclaimed "You didn't approach my door as I told you in my letter." Despite this startling welcome the visit went well. She was completely deaf, so our questions had to be written and handed to her. Her replies were all one could wish. Nothing was held back. She had suffered a stroke which left her left side paralyzed. Still she lived alone and dragged herself upstairs to bed with her right hand gripping the banister. She walked with the help of a stick and while we were there she moved around and at the end showed us her little garden outside the back door. In it was a large bush which she informed me was a rosemary bush. We learned that after she broke off with Russell for the last time she had sent him a dozen red roses every year on his birthday. Ken and I decided to honour her in the same way. Her heartfelt letters of thanks were our rewards.

In June of that same year I decided to go to Britain again to search for early Russell books in second-hand shops. The arrival of the archives had spurred a desire to assemble as complete a collection of his output as I could, and London was an ideal place to start. Just before I was due to leave Ready sent me a copy of a long telegram he had received from a United States publisher who requested that Ronald W. Clark, the author of a major life of Einstein, be given access to the archives for a first major biography of Russell. Would I please visit Clark while I was in London and report back to Ready on whether, in my opinion, he should be given access? I said I would, and when I got to London I contacted Clark and was invited to dinner at his home. My conversations with Ronald and his wife Pearla, both before and during a delicious dinner, convinced me, as I told Ready, that they could be trusted to produce a well-researched life of Russell. That first meeting led to a lifelong friendship with both of the Clarks. I began to stay with them on my annual 
trips to London. I read Clark's book in typescript and was able to help him with his attempts to convey to his readers some idea of Russell's philosophical originality. My last conversation with Ronald occurred by telephone about an hour before he suffered a massive stroke from which he died a few days later. Pearla and I remained friends until she died from liver cancer. Indeed, I accompanied her to the appointment where she was given the grim news. She was a lovely person who had endured many disappointments in her life without allowing them to destroy her cheerful disposition.

Those years were very busy ones for me, for in addition to my work for the archives, I was also from 1969 until 1974 the chairman of the largest philosophy department in Canada. I had taken on that job with a promise to transform its governance from a top-down autocracy to one whose important decisions were made by committees of faculty and students. In retrospect I do not know how I found the time to do it all, but I am very grateful that events so conspired as to offer me the challenge. And as Russell was wont to say about his life, if offered the chance, I would gladly do it again.

WORKS CITED

Clark, Ronald W. The Life of Bertrand Russell. London: Jonathan Cape and Weidenfeld \& Nicolson, I975.

Ready, William. "Introduction" to Slater and Blackwell, p. 4.
Slater, John G., ANd Kenneth BlackWELL. "The Collected Essays of Bertrand Russell: Prospectus of the Edition", Russell o.s. no. I2 (Winter I973-74): 5-IO, I9-27. 